A N N A L ES

UNIVERSITATIS MARIAE CURIE-SKŁODOWSKA

LUBLIN - POLONIA

VOL. LXII, 2

SECTIO G

2015

MARIUSZ WIECZOREK

\title{
Zabezpieczenie społeczne funkcjonariuszy Służby Celnej w świetle konstytucyjnej zasady równości
}

Social Security of the Customs Service Officers in the Light of the Constitutional Principle of Equality

Celem niniejszego artykułu jest przedstawienie niektórych aspektów zabezpieczenia społecznego funkcjonariuszy Służby Celnej. W obecnym stanie prawnym pełnienie służby przez celników jest, zgodnie z art. 6. ust. 1 pkt 18a ustawy z dnia 13 października 1998 roku o systemie ubezpieczeń społecznych ${ }^{1}$, tytułem ubezpieczenia społecznego. Oznacza to, że celnicy, inaczej niż funkcjonariusze innych służb mundurowych, objęci są tzw. ubezpieczeniową techniką zabezpieczenia społecznego zapewniającą niższy, w porównaniu do systemu zaopatrzeniowego zorganizowanego dla funkcjonariuszy, poziom ochrony socjalnej. Różnica ta jest szczególnie widoczna w określeniu granicy wieku emerytalnego i budzi w tej grupie zawodowej poczucie niesprawiedliwości i dyskryminacji. Przyczynkiem do podjęcia tego zagadnienia jest wyrok Trybunału Konstytucyjnego z dnia 3 marca 2015 roku $^{2}$, w którym Trybunał za niekonstytucyjne uznał pominięcie niektórych funkcjonariuszy Służby Celnej ${ }^{3}$ w ustawie z dnia 18 lutego 1994 roku o zaopatrzeniu emerytalnym funkcjonariuszy Policji, Agencji Bezpieczeństwa Wewnętrznego, Agencji Wywiadu, Służby Kontrwywiadu Wojskowego, Służby Wywiadu Wojskowego, Centralnego Biura Antykorupcyjnego,

1 Ustawa z dnia 13 października 1998 roku o systemie ubezpieczeń społecznych (t.j. Dz.U. z 2013 roku, poz. 1442 ze zm.).

2 Wyrok Trybunału Konstytucyjnego z dnia 3 marca 2015 roku, K 39/13, dalej jako: wyrok TK w sprawie uprawnień emerytalnych funkcjonariuszy SC.

3 Z uwagi na rodzaj opracowania nie może ono być postrzegane jako próba wszechstronnego i wyczerpującego przedstawienia wszystkich aspektów podejmowanych zagadnień. 
Straży Granicznej, Biura Ochrony Rządu, Państwowej Straży Pożarnej i Służby Więziennej oraz ich rodzin ${ }^{4}$.

\section{WPROWADZENIE}

Pojęcie „zabezpieczenie społeczne” pojawiło się w latach 30. XX wieku w Stanach Zjednoczonych w związku z przyjęciem w 1935 roku ustawy Social Security Act i chociaż dość szybko weszło do języka prawniczego oraz zaczęło pojawiać się w prawie międzynarodowym ${ }^{5}$, to przez dość długi czas nie doczekało się jednoznacznej definicji ${ }^{6}$. W Polsce jedną z pierwszych prób w tym kierunku podjął J. Piotrowski, zdaniem którego zabezpieczenie społeczne to całokształt środków i działań instytucji publicznych, za pomocą których społeczeństwo stara się zabezpieczyć swoich obywateli przed niezawinionym przez nich niedostatkiem, przed groźbą niemożności zaspokojenia podstawowych, społecznie uznanych za ważne potrzeb ${ }^{7}$. Według innego poglądu przywołanego autora zabezpieczenie społeczne to całokształt urządzeń publicznych zapewniających ochronę przed niedostatkiem, natomiast ubezpieczenie społeczne, zaopatrzenie społeczne, opieka czy pomoc społeczna stanowią nie tyle działy zabezpieczenia społecznego, ile techniki jego realizacji ${ }^{8}$. Podobnie zabezpieczenie społeczne postrzega I. Jędrasik-Jankowska, która w oparciu o kryterium metod i środków w dziedzinie sposobu gromadzenia zasobów materialnych niezbędnych do zaspokajania potrzeb i zasad rozdysponowywania nagromadzonych środków rozróżnia technikę ubezpieczeniową, zaopatrzeniową i opiekuńczą9.

O prawie do zabezpieczenia stanowi art. 67 Konstytucji Rzeczypospolitej Polskiej ${ }^{10}$, zgodnie z którym prawo to przysługuje obywatelom w razie niezdolności do pracy z powodu choroby, inwalidztwa i po osiągnięciu wieku emerytal-

4 Ustawa z dnia 18 lutego 1994 roku o zaopatrzeniu emerytalnym funkcjonariuszy Policji, Agencji Bezpieczeństwa Wewnętrznego, Agencji Wywiadu, Służby Kontrwywiadu Wojskowego, Służby Wywiadu Wojskowego, Centralnego Biura Antykorupcyjnego, Straży Granicznej, Biura Ochrony Rządu, Państwowej Straży Pożarnej i Służby Więziennej oraz ich rodzin (t.j. Dz.U. z 2013 roku, poz. 667 ze zm.).

5 Szczególne znaczenie w omawianym zakresie mają zwłaszcza konwencje Międzynarodowej Organizacji Pracy z Konwencją nr 102 dotyczącą minimalnych norm zabezpieczenia społecznego na czele.

6 Zob. B. Schulte, Reformy zabezpieczenia spolecznego w Europie, [w:] Referaty na VI Europejski Kongres Prawa Pracy i Zabezpieczenia Społecznego, Warszawa 1999, s. 209.

7 J. Piotrowski, Zabezpieczenie społeczne. Problematyka i metody, Warszawa 1966, s. 29.

8 Ibidem, s. 13. Więcej o sposobach pojmowania zabezpieczenia społecznego zob. J. Wantoch-Rekowski, System ubezpieczeń społecznych a budżet państwa. Studium prawno-finansowe, Warszawa 2014.

9 I. Jędrasik-Jankowska, Ubezpieczenie społeczne, t. 1: Czesść ogólna, Warszawa 2003, s. 18 i n. ze zm.).

Konstytucja Rzeczypospolitej Polskiej z dnia 2 kwietnia 1997 roku (Dz.U., nr 78, poz. 483 
nego (ust. 1) oraz w sytuacji, gdy bez własnej woli pozostają bez pracy i nie mają środków utrzymania (ust. 2). Zakres i formy zabezpieczenia społecznego w razie zaistnienia wskazanych zdarzeń określa ustawodawca zwykły, który w tym zakresie ma znaczną swobodę.

W świetle ugruntowanego poglądu Trybunału Konstytucyjnego ${ }^{11}$ art. 67 Konstytucji stanowi podstawę do rozróżnienia: 1) minimalnego zakresu prawa do zabezpieczenia społecznego odpowiadającego konstytucyjnej istocie tego prawa, który ustawodawca ma obowiązek zagwarantować, 2) sfery uprawnień zagwarantowanych przez ustawę i wykraczających poza konstytucyjną istotę rozważanego prawa.

W pierwszym wypadku ustawodawca ma wyraźnie zawężony margines swobody przy wprowadzaniu zmian do systemu prawnego. Nowe rozwiązania prawne nie mogą bowiem naruszać konstytucyjnej istoty prawa do zabezpieczenia społecznego, które przysługuje wszystkim obywatelom. W drugim wypadku ustawodawca może co do zasady ograniczyć lub w skrajnym przypadku konieczności gospodarczej znieść uprawnienia wykraczające poza konstytucyjną istotę prawa do zabezpieczenia społecznego ${ }^{12}$. W zakres przysługującej prawodawcy swobody kształtowania systemu zabezpieczenia społecznego wchodzi nie tylko poziom ochrony socjalnej, ale również stosowana technika.

W wyroku TK w sprawie uprawnień emerytalnych funkcjonariuszy S.C. została rozstrzygnięta wątpliwość co do zgodności art. 1, art. 18a i art. 18b ust. 1 ustawy o zaopatrzeniu emerytalnym funkcjonariuszy z Konstytucją RP. Wątpliwości wnioskodawców ${ }^{13}$ budziło wyłączenie spod zakresu podmiotowego ustawy o zaopatrzeniu emerytalnym funkcjonariuszy celników, co ich zdaniem miało naruszać zasadę równości, wywodzoną z art. 2 Konstytucji zasadę zaufania do państwa i stanowionego przezeń prawa, a także zasadę sprawiedliwości społecznej. Ponadto wnioskodawcy podnosili również zarzut niezgodności przywołanych przepisów z art. 67 ust. 1 Konstytucji. Na rzecz objęcia funkcjonariuszy Służby Celnej zaopatrzeniem społecznym miałyby, ich zdaniem, przemawiać specyfika stosunku służby i swoistość ryzyka, zaś cechą relewantną była przynależność do służb mundurowych. Trybunał Konstytucyjny tylko częściowo podzielił powyższe wątpliwości, jako że

11 Zob. np. wyrok Trybunału Konstytucyjnego: z dnia 7 lutego 2006 roku, sygn. akt SK 45/04, OTK ZU nr 2/A/2006; z dnia 11 grudnia 2006 roku, sygn. akt SK 15/0, OTK ZU nr 11/A/2006, poz. 170; z dnia 29 kwietnia 2008 roku, P 38/06, OTK ZU nr 3/A/2008, poz. 46.

12 Wyrok Trybunału Konstytucyjnego z dnia 19 grudnia 2012 roku, K 9/12.

13 Grupa Posłów na Sejm RP VII kadencji, Związek Zawodowy Celnicy PL, Zrzeszenie Związków Zawodowych Służby Celnej RP, Federacja Związków Zawodowych Służby Celnej. Zob. Trybunat Konstytucyjny - dokumenty w sprawie K 39/13, http://otk.trybunal.gov.pl/orzeczenia/ezd/sprawa_lista_plikow.asp?syg=K\%2039/13 [data dostępu: 24.03.2015]; Trybunat Konstytucyjny - dokumenty w sprawie K 56/13, http://otk.trybunal.gov.pl/OTK/ezd/sprawa_lista_plikow. asp?syg=K\%2056/13 [data dostępu: 24.03.2015]; Trybunat Konstytucyjny - dokumenty w sprawie K 57/13, http://otk.trybunal.gov.pl/OTK/ezd/sprawa_lista_plikow.asp?syg=K\%2057/13 [data dostępu: 24.03.2015]. 
co do zasady zaaprobował objęcie celników techniką ubezpieczeniową, ale równocześnie uznał, że część z nich, tj. ci, którzy wykonują zadania określone w art. 2 ust. 1 pkt. 4-6 ustawy z dnia 27 sierpnia 2009 roku o Służbie Celnej ${ }^{14}$, powinna być włączona w zakres podmiotowy ustawy o zaopatrzeniu emerytalnym funkcjonariuszy.

Podejmując podstawowy cel niniejszego opracowania, należy rozważyć, czy istnieją okoliczności pozwalające na uznanie, iż wszyscy funkcjonariusze Służby Cywilnej powinni być, w świetle konstytucyjnych zasad równości i sprawiedliwości społecznej, objęci zaopatrzeniową techniką zabezpieczenia społecznego. Punktem wyjścia do dalszych rozważań niech będą słowa Ch. Perelmana: „Aby należeć do tej samej kategorii istotnej, nie wystarczy posiadać tę samą określoną cechę charakterystyczną, trzeba ją posiadać w tym samym stopniu. Nie wystarczy, że dwie osoby mają jednakowe zasługi, by były jednakowo traktowane, muszą miećże w tym samym stopniu"15. Dalsze wywody skoncentrują się na próbie odpowiedzi na pytanie o to, czy w związku z wykonywaniem zawodu celnika można mówić o cesze relewantnej, która uzasadnia szczególne, uprzywilejowane potraktowanie tej grupy w kontekście zabezpieczenia emerytalnego ${ }^{16}$.

\section{SPECYFIKA STOSUNKU SŁUŻBOWEGO FUNKCJONARIUSZY SC}

W art. 1 ust. 1 ustawy z dnia 27 sierpnia 2009 roku o Służbie Celnej została ona określona jako jednolita umundurowana formacja, utworzona w celu zapewnienia ochrony i bezpieczeństwa obszaru celnego Unii Europejskiej, w tym zgodności z prawem przywozu towarów na ten obszar oraz wywozu towarów z tego obszaru, a także wykonywania obowiązków określonych w przepisach odrębnych, w szczególności w zakresie podatku akcyzowego oraz podatku od gier.

Służbę Celną tworzą funkcjonariusze pozostający w regulowanym prawem administracyjnym stosunku służbowym ${ }^{17}$. Stosunek służbowy funkcjonariusza

14 Ustawa z dnia 27 sierpnia 2009 roku o Służbie Celnej (t.j. Dz.U. z 2013 roku, poz. 1404 ze zm.), dalej jako: u.S.C.

15 Ch. Perelman, O sprawiedliwości, Warszawa 1959, s. 41. Zob. też: Orzeczenie Trybunału Konstytucyjnego z dnia 9 marca 1988 roku, sygn. akt U 7/87, OTK 1988, cz. I, poz. 1.

16 Opracowanie powstało przy założeniu, że nie wymagają wyjaśnienia zasady równości i sprawiedliwości społecznej. Na ten temat zob. m.in. Z. Ziembiński, Sprawiedliwość społeczna jako pojęcie prawne, Warszawa 1996; S. Tkacz, Rozumienie sprawiedliwości w orzecznictwie Trybunału Konstytucyjnego, Katowice 2003; J. Karp, Sprawiedliwość społeczna, Kraków 2004.

17 Zob. np. wyrok Wojewódzkiego Sądu Administracyjnego w Warszawie z dnia 23 stycznia 2007 roku, II SA/Wa 2031/06, LEX nr 299847; uchwała Sądu Najwyższego z dnia 5 czerwca 2008 roku, II PZP 9/08, LEX nr 393793; wyrok Wojewódzkiego Sądu Administracyjnego w Warszawie z dnia 8 listopada 2010 roku, II SAB/Wa 180/10, LEX nr 756185; uchwała Sądu Najwyższego z dnia 8 czerwca 2010 roku, II PZP 5/10, LEX nr 577806. Tak też: T. Kuczyński, Pojęcie i przedmiot prawa stosunków stużbowych, [w:] System prawa administracyjnego, t. 11: Stosunek slużbowy, pod red. R. Hausera, Z. Niewiadomskiego, A. Wróbla, Warszawa 2011, s. 16 i n. 
celnego, zgodnie $\mathrm{z}$ art. 78 ust. 1 u.S.C., powstaje $\mathrm{w}$ drodze mianowania na podstawie dobrowolnego zgłoszenia się do służby. Wynika z tego, że konsensusu stron wymaga jedynie zadecydowanie o przyjęciu do służby, a nie ustalenie warunków pełnienia tej służby. Istotą służby jest zaś dyspozycyjność funkcjonariuszy i dlatego temu stosunkowi służbowemu nadano charakter stosunku administracyjnoprawnego, a więc takiego, w którym organ jednostronnie i władczo kształtuje sytuację prawną funkcjonariusza. Dla stosunków służbowych stanowiących podstawę pełnienia służby w tzw. formacjach mundurowych, w tym dla celników, charakterystyczną cechą jest podległość służbowa, a zwierzchnik, inaczej niż przełożony pracownika $\mathrm{w}$ stosunku pracy, zyskuje znaczną dyskrecjonalną władzę kształtowania sytuacji prawnej podwładnego. Zauważyć należy, że stosunek służbowy, w jakim pozostaje funkcjonariusz Służby Celnej, ma taki sam charakter prawny, jak stosunki służbowe w innych służbach mundurowych, a regulacje ustawowe odnoszące się do funkcjonariusza Służby Celnej nie odbiegają prima facie w istotny sposób od dotyczących funkcjonariuszy innych służb.

W tym miejscu należy jednak postawić pytanie, czy charakter prawny tego stosunku stanowi wystarczające uzasadnienie dla uprzywilejowania socjalnego, przede wszystkim emerytalnego, funkcjonariuszy. W tym celu konieczne jest porównanie służby celników, rozumianej w dużym uogólnieniu jako zakres obowiązków służbowych, ze służbą pozostałych funkcjonariuszy objętych ustawą o zaopatrzeniu emerytalnym funkcjonariuszy.

W świetle podstawowej definicji terminu ,służba” jest nią praca na rzecz jakiejś wspólnoty, wykonywana z poświęceniem ${ }^{18}$. Niezwykłość służby, jako szczególnego rodzaju pracy ${ }^{19}$, wynika przede wszystkim z roty ślubowania, jaką wypowiadają funkcjonariusze poszczególnych służb, a która zobowiązuje ich do wykonywania zadań polegających $\mathrm{w}$ dużym skrócie i uproszczeniu na służbie publicznej. Zgodnie z art. 27 ust. 1 ustawy z dnia 6 kwietnia 1990 roku o Policji (t.j. Dz.U. z 2011 roku, nr 287, poz. 1687 ze zm.) przed podjęciem służby policjant składa ślubowanie, w którym ślubuje „służyć wiernie Narodowi, chronić ustanowiony Konstytucją Rzeczypospolitej Polskiej porządek prawny, strzec bezpieczeństwa państwa i jego obywateli, nawet z narażeniem życia". Według podobnej roty składają ślubowanie funkcjonariusze Straży Granicznej. Zgodnie z art. 33 ust. 1 ustawy z dnia 12 października 1990 roku o Straży Granicznej (t.j. Dz.U. z 2014 roku, poz. 1402) przed podjęciem służby funkcjonariusz Straży Granicznej składa ślubowanie, w którym ślubuje „służyć wiernie Narodowi Polskiemu, mając zawsze na względzie interes Państwa Polskiego [...] stać nieugięcie na straży

18 Hasło: Stużba, http://sjp.pwn.pl/sjp/;2521967 [data dostępu: 29.03.2015]

19 M. Wieczorek, Prawne podstawy zatrudnienia w Agencji Bezpieczeństwa Wewnętrznego, [w:] Prawo bezpieczeństwa publicznego, pod red. M. Karpiuka, K. Walczuka, Warszawa 2013, s. $195 \mathrm{i} \mathrm{n.}$ 
niepodległości i suwerenności oraz strzec nienaruszalności granicy państwowej Rzeczypospolitej Polskiej, nawet z narażeniem życia”. Z kolei strażak, podejmując służbę w Państwowej Straży Pożarnej, ślubuje „być ofiarnym i mężnym w ratowaniu zagrożonego życia ludzkiego i wszelkiego mienia - nawet z narażeniem życia" ${ }^{20}$. Podobnie funkcjonariusz Biura Ochrony Rządu, zgodnie z art. 22 ustawy z dnia 16 marca 2001 roku o Biurze Ochrony Rządu ${ }^{21}$, przed podjęciem służby ślubuje „służyć wiernie Narodowi Polskiemu, mając zawsze na względzie interes Państwa Polskiego, nawet z narażeniem własnego życia”. Funkcjonariusze CBA również składają ślubowanie, w rocie którego, jak stanowi art. 51 ust. 1 ustawy z dnia 9 czerwca 2006 roku o Centralnym Biurze Antykorupcyjnym ${ }^{22}$, przysięgają ,służyć wiernie Narodowi, pilnie przestrzegać prawa, dochować wierności konstytucyjnym organom Rzeczypospolitej Polskiej, sumiennie i bezstronnie wykonywać obowiązki funkcjonariusza Centralnego Biura Antykorupcyjnego, nawet z narażeniem życia”. Gotowość do pełnienia służby nawet z narażeniem życia deklarują także funkcjonariusze Agencji Bezpieczeństwa Wewnętrznego oraz funkcjonariusze Agencji Wywiadu. Jak stanowi rota ślubowania funkcjonariuszy, zawarta w art. 47 ust. 1 ustawy z dnia 24 maja 2002 roku o Agencji Bezpieczeństwa Wewnętrznego oraz Agencji Wywiadu ${ }^{23}$, ślubują oni „służyć wiernie Narodowi, chronić ustanowiony Konstytucją Rzeczypospolitej Polskiej porządek prawny, strzec bezpieczeństwa Państwa i jego obywateli, nawet z narażeniem życia". Zobowiązanie do pełnienia służby z narażeniem życia expressis verbis wynika też z roty przysięgi składanej przez funkcjonariuszy Służby Kontrwywiadu Wojskowego oraz Służby Wywiadu Wojskowego, określonego w art. 6 ust. 1 ustawy z dnia 9 czerwca 2006 roku o służbie funkcjonariuszy Służby Kontrwywiadu Wojskowego oraz Służby Wywiadu Wojskowego ${ }^{24}$. Funkcjonariusz SKW (i SWW) przysięga „służyć wiernie Rzeczypospolitej Polskiej i stać na straży Konstytucji [...], sumiennie i bezstronnie wykonywać obowiązki funkcjonariusza, w potrzebie z narażeniem życia".

W rocie pisemnego ślubowania, którego treść wyznacza art. 81 u.S.C., składanego pisemnie przez funkcjonariuszy Służby Celnej przed podjęciem służby, nie znalazło się zobowiązanie do gotowości poświęcenia zdrowia ani tym bardziej życia funkcjonariusza. Nie powinna budzić większych wątpliwości teza, że roty

20 Art. 30 ust. 1 ustawy z dnia 24 sierpnia 1991 roku o Państwowej Straży Pożarnej (t.j. Dz.U. z 2013 roku, poz. 1340 ze zm.).

21 Ustawa z dnia 16 marca 2001 roku o Biurze Ochrony Rządu (t.j. Dz.U. z 2014 roku, poz. 170).

22 Ustawa z dnia 9 czerwca 2006 roku o Centralnym Biurze Antykorupcyjnym (t.j. Dz.U. z 2014 roku, poz. 1411).

23 Ustawa z dnia 24 maja 2002 roku o Agencji Bezpieczeństwa Wewnętrznego oraz Agencji Wywiadu (t.j. Dz.U. z 2010 roku, nr 29, poz. 154 ze zm.).

24 Ustawa z dnia 9 czerwca 2006 roku o służbie funkcjonariuszy Służby Kontrwywiadu Wojskowego oraz Służby Wywiadu Wojskowego (t.j. Dz.U. z 2014 roku, poz. 1106). 
ślubowań oddają istotę obowiązków wykonywanych przez funkcjonariuszy poszczególnych służb mundurowych. Jak wyżej stwierdzono, służba jest pracą, ale nie może być traktowana jak inne przejawy aktywności zarobkowej człowieka. Służba nie jest „zwykłą” pracą najemną. W szczególności za służbę nie można jednak uznać pracy wykonywanej przez pracownika w ramach stosunku pracy. Prawo pracy nie wymaga bowiem od pracowników gotowości do szafowania ich zdrowiem, nie mówiąc o życiu, a wręcz przeciwnie. Jak stanowi art. $210 \S 1$ Kodeksu pracy ${ }^{25}, \mathrm{w}$ razie gdy warunki pracy nie odpowiadają przepisom bezpieczeństwa i higieny pracy i stwarzają bezpośrednie zagrożenie dla zdrowia lub życia pracownika albo gdy wykonywana przez niego praca grozi takim niebezpieczeństwem innym osobom, pracownik ma prawo powstrzymać się od wykonywania pracy, zawiadamiając o tym niezwłocznie przełożonego. $Z$ kolei pełnienie służby przez funkcjonariuszy służb mundurowych bardzo często wiąże się z działaniem w okolicznościach, w których stan zagrożenia ich życia i zdrowia stanowi nieodłączną część składającą się na warunki służby. Nieprzypadkowo ustawodawca w poszczególnych pragmatykach służbowych nie stanowi o prawie funkcjonariuszy do bezpiecznych i higienicznych warunków pracy, ale do bezpiecznych i higienicznych warunków służby. Gdyby zakres prawa pracowników i funkcjonariuszy był identyczny, ustawodawca nie wprowadzałby tego rozróżnienia. Specyfika zadań wykonywanych przez funkcjonariuszy jest tego rodzaju, że nie sposób przewidzieć wystąpienia okoliczności implikujących konieczność podjęcia przez funkcjonariusza działań grożących jego zdrowiu czy życiu. Przestrzeganie przez funkcjonariuszy przepisów bezpieczeństwa i higieny służby tylko w pewnym zakresie pozwala na ograniczenie ryzyka służbowego, ale nie gwarantuje, że funkcjonariusz pełniący służbę nie dozna uszczerbku na zdrowiu. Funkcjonariusze służb mundurowych, deklarujący gotowość poświęcenia dobra indywidualnego w imię ochrony dobra publicznego, akceptują, że w trakcie wykonywania swoich obowiązków będą ponosić specyficzne „ryzyko służbowe”, rozumiane jako zagrożenia, których źródłem są przestępcze działania ludzi bądź siły przyrody, których następstwem może być uszczerbek na zdrowiu, a nawet śmierć.

Uwagi dotyczące „ryzyka służbowego" nie odnoszą się w pełnym zakresie do funkcjonariuszy Służby Celnej. Wnioski płynące $\mathrm{z}$ analizy art. 1 ust. 1 ustawy o SC pozwalają na postawienie tezy, że wśród obowiązków celników można wyodrębnić dwie zasadnicze grupy: 1) czynności, które stanowią służbę sensu stricte, 2) czynności, których wykonanie nie odpowiada wskazanemu wyżej sposobowi rozumienia służby. Do pierwszej grupy należą obowiązki wykonywane w związku z zadaniami Służby Celnej określonymi w art. 2 ust. 1 pkt. 4-6 ustawy o SC, które obejmują rozpoznawanie, wykrywanie, zapobieganie i zwalczanie określonych w przywołanych przepisach kategorii przestępstw i wykroczeń.

25 Ustawa z dnia 26 czerwca 1974 roku - Kodeks pracy (t.j. Dz.U. z 2014 roku, poz. 1502 ze zm.). 
Funkcjonariusze wykonujący te obowiązki nie tylko tak jak policjanci pozostają w stosunku służbowym, ale muszą liczyć się z prawdopodobieństwem powstania zagrożeń dla ich zdrowia i życia.

Jednakże, jak słusznie zauważył Prokurator Generalny ${ }^{26}$, gros obowiązków nałożonych na SC koncentruje się na zadaniach o charakterze administracyjnym, takich jak wykonywanie czynności związanych z nadawaniem towarom przeznaczenia celnego, naliczanie i pobór podatków oraz należności celnych, wykonywanie kontroli w zakresie wywiązywania się podmiotów z obowiązków w zakresie kontroli określonych podatków, udzielania koncesji i zezwoleń, zatwierdzanie regulaminów oraz rejestracja urządzeń określonych w ustawie o grach hazardowych czy współdziałanie przy realizacji Wspólnej Polityki Rolnej. Służbie celników, rozumianej jako rodzaj aktywności zawodowej, zdecydowanie bliżej do zadań, jakie wykonują członkowie korpusu służby cywilnej zatrudnieni w urzędzie obsługującym ministra właściwego do spraw finansów publicznych i w jednostkach organizacyjnych podległych lub nadzorowanych przez tego ministra. Wniosek ten potwierdza treść art. 98-99 ustawy o Służbie Cywilnej. Przewidują one odpowiednio możliwość przejścia funkcjonariusza Służby Celnej do korpusu służby cywilnej, a członka korpusu służby cywilnej do Służby Celnej. Dopuszczenie tego rodzaju „transferu” jest oparte, jak się wydaje, na zbliżonej naturze obowiązków wykonywanych przez celników i członków korpusu służby cywilnej zatrudnionych w jednostkach „administracji finansowej”. Doświadczenie zawodowe zdobywane w Służbie Celnej i w aparacie podatkowym uzasadniają odstąpienie od weryfikacji przydatności do służby/pracy w tych obszarach.

Dodatkowego argumentu na rzecz zaprezentowanego sposobu postrzegania specyfiki służby dostarczają wnioski z analizy przewidzianego w art. 25a ust. 1 i 3 ustawy z dnia 6 kwietnia o Policji ${ }^{27}$ unormowania, zgodnie z którym funkcjonariusza Straży Granicznej, Biura Ochrony Rządu, Służby Celnej, Państwowej Straży Pożarnej, Agencji Bezpieczeństwa Wewnętrznego, Agencji Wywiadu, Służby Wywiadu Wojskowego, Służby Kontrwywiadu Wojskowego lub Centralnego Biura Antykorupcyjnego można przenieść do służby w Policji, jeśli wykazuje on szczególne predyspozycje do jej pełnienia. W świetle art. 25a ust. 1 ustawy podstawową przesłanką przeniesienia są „,szczególne predyspozycje do służby w Policji". Predyspozycje te mogą ujawnić się jedynie w związku z wykonywaniem obowiązków rodzajowo bliskich służbie policjantów. Jednakże funkcjonariusz Służby Celnej przeniesiony do służby w Policji nie zachowuje, jak stanowi art.

26 Stanowisko Prokuratora Generalnego w odniesieniu do wniosków dotyczacych ustawy o emeryturach mundurowych, s. 35-36, http://pg.gov.pl/rok-2014-1901/stanowisko-prokuratorageneralnego-w-odniesieniu-do-wnioskow-dotyczacych-ustawy-o-emeryturach-mundurowych. html\#.VRup2PysVto [data dostępu: 31.03.2015].

27 Ustawa z dnia 6 kwietnia 1990 roku o Policji (t.j. Dz.U. z 2015 roku, poz. 1505). 
25a ust. 3 ustawy o Policji, ciągłości służby. Wydaje się zatem, że pominięcie przez ustawodawcę w art. 25a ust. 3 ustawy o Policji Służby Celnej jest konsekwencją odmiennego postrzegania zadań wykonywanych przez funkcjonariuszy sensu stricte oraz służby celników. Prawodawca zauważa „,cywilny” co do zasady charakter obowiązków celników, co sprawia, że w trakcie ich wykonywania nie mogą ujawnić się predyspozycje do pełnienia służby w Policji. Wykonywanie obowiązków polegających na nadawaniu towarom przeznaczenia celnego, wymiarze i poborze niektórych podatków i opłat, stanowiące podstawowe zadanie Służby Celnej, może być uznane za „pracę na rzecz jakiejś wspólnoty”, ale w tego rodzaju działaniach brak elementu poświęcenia, co uniemożliwia uznaniu ich za służbę w znaczeniu ścisłym.

\section{PODSUMOWANIE}

Nie ulega wątpliwości, że system emerytalny zorganizowany dla funkcjonariuszy służb mundurowych stanowi wyraz socjalnego uprzywilejowania, a jego najważniejszym aspektem jest niższy, w porównaniu do określonego w przepisach prawa ubezpieczeń społecznych, wiek uprawniający do emerytury. Ustawodawca, wprowadzając przedmiotowe uprzywilejowanie, zastosował formułę sprawiedliwości: „każdemu według zasług”28. Jakkolwiek pozostawanie w regulowanym prawem administracyjnym stosunku służbowym jest okolicznością, która obiektywnie wyodrębnia pewną grupę zawodową spośród ogółu osób wykonujących zatrudnienie, to samo w sobie nie stanowi zasługi. Może być za nią uznane pełnienie służby sensu stricte, a zatem wykonywanie obowiązków, w trakcie których mogą zaistnieć okoliczności tego rodzaju, że zagrożone będzie zdrowie, a nawet życie funkcjonariusza, do czego zobowiązuje się on przed podjęciem służby.

W świetle powyższych wywodów uzasadnione jest stanowisko Trybunału Konstytucyjnego, który w wyroku o uprawnieniach emerytalnych funkcjonariuszy Służby Celnej uznał, że tylko część funkcjonariuszy SC powinna korzystać $\mathrm{z}$ uprzywilejowania $\mathrm{w}$ zakresie zabezpieczenia emerytalnego. Efektem wyroku będzie zatem pełniejsze zrealizowanie konstytucyjnych zasad równości i sprawiedliwości społecznej

Warto jednak zauważyć, że wyrok Trybunału Konstytucyjnego rodzi szereg wyzwań dla ustawodawcy, które nie ograniczą się do konieczności przeprowadzenia zmian ustawy o zaopatrzeniu emerytalnym funkcjonariuszy. Logicznym następstwem przedmiotowego wyroku TK będzie konieczność zrównania celników wykonujących zadania określone $\mathrm{w}$ art. 2 ust. 1 pkt. 4-6 u.S.C. $\mathrm{z}$ funkcjonariuszami sensu stricte w zakresie wszystkich postaci ryzyka socjalnego, a w szczegól-

28 Z. Ziembiński, O pojmowaniu sprawiedliwości, Lublin, s. 121 i n.; Ch. Perelman, op. cit., s. $41 \mathrm{i} \mathrm{n.}$ 
ności niezdolności do służby z powodu choroby. Oznacza to, że grupa celników, o której mowa, będzie musiała być „wydzielona” z systemu ubezpieczeniowego i „przeniesiona” do systemu zaopatrzeniowego, co oznacza konieczność kompleksowych działań na poziomie ustaw oraz aktów wykonawczych.

\section{BIBLIOGRAFIA}

Jędrasik-Jankowska I., Ubezpieczenie społeczne, t. 1: Cześć ogólna, Warszawa 2003.

Karp J., Sprawiedliwość społeczna, Kraków 2004.

Konstytucja Rzeczypospolitej Polskiej z dnia 2 kwietnia 1997 roku (Dz.U., nr 78, poz. 483 ze zm.). Kuczyński T., Pojęcie i przedmiot prawa stosunków stużbowych, [w:] System prawa administracyjnego, t. 11: Stosunek stużbowy, pod red. R. Hausera, Z. Niewiadomskiego, A. Wróbla, Warszawa 2011.

Orzeczenie Trybunału Konstytucyjnego z dnia 9 marca 1988 roku, sygn. akt U 7/87, OTK 1988, cz. I, poz. 1.

Perelman Ch., O sprawiedliwości, Warszawa 1959.

Piotrowski J., Zabezpieczenie społeczne. Problematyka i metody, Warszawa 1966.

Schulte B., Reformy zabezpieczenia społecznego w Europie, [w:] Referaty na VI Europejski Kongres Prawa Pracy i Zabezpieczenia Społecznego, Warszawa 1999.

Hasło: Stużba, http://sjp.pwn.pl/sjp/;2521967 [data dostępu: 29.03.2015].

Stanowisko Prokuratora Generalnego w odniesieniu do wniosków dotyczących ustawy o emeryturach mundurowych, http://pg.gov.pl/rok-2014-1901/stanowisko-prokuratora-generalnego-wodniesieniu-do-wnioskow-dotyczacych-ustawy-o-emeryturach-mundurowych.html\#.VRup2PysVto [data dostępu: 31.03.2015].

Tkacz S., Rozumienie sprawiedliwości w orzecznictwie Trybunału Konstytucyjnego, Katowice 2003.

Trybunat Konstytucyjny - dokumenty w sprawie K 39/13, http://otk.trybunal.gov.pl/orzeczenia/ezd/ sprawa_lista_plikow.asp?syg=K\%2039/13 [data dostępu: 24.03.2015].

Trybunat Konstytucyjny - dokumenty w sprawie K 56/13, http://otk.trybunal.gov.pl/OTK/ezd/sprawa_lista_plikow.asp?syg=K\%2056/13 [data dostępu: 24.03.2015].

Trybunat Konstytucyjny - dokumenty w sprawie K 57/13, http://otk.trybunal.gov.pl/OTK/ezd/sprawa_lista_plikow.asp?syg=K\%2057/13 [data dostępu: 24.03.2015].

Uchwała Sądu Najwyższego z dnia 5 czerwca 2008 roku, II PZP 9/08, LEX nr 393793.

Uchwała Sądu Najwyższego z dnia 8 czerwca 2010 roku, II PZP 5/10, LEX nr 577806.

Ustawa z dnia 26 czerwca 1974 roku - Kodeks pracy (t.j. Dz.U. z 2014 roku, poz. 1502 ze zm.).

Ustawa z dnia 6 kwietnia 1990 roku o Policji (t.j. Dz.U. z 2015 roku, poz. 1505).

Ustawa z dnia 12 października 1990 roku o Straży Granicznej (t.j. Dz.U. z 2014 roku, poz. 1402).

Ustawa z dnia 24 sierpnia 1991 roku o Państwowej Straży Pożarnej (t.j. Dz.U. z 2013 roku, poz. $1340 \mathrm{ze} \mathrm{zm}$.).

Ustawa z dnia 18 lutego 1994 roku o zaopatrzeniu emerytalnym funkcjonariuszy Policji, Agencji Bezpieczeństwa Wewnętrznego, Agencji Wywiadu, Służby Kontrwywiadu Wojskowego, Służby Wywiadu Wojskowego, Centralnego Biura Antykorupcyjnego, Straży Granicznej, Biura Ochrony Rządu, Państwowej Straży Pożarnej i Służby Więziennej oraz ich rodzin (t.j. Dz.U. z 2013 roku, poz. 667 ze zm.).

Ustawa z dnia 13 października 1998 roku o systemie ubezpieczeń społecznych (t.j. Dz.U. z 2013 roku, poz. 1442 ze zm.).

Ustawa z dnia 16 marca 2001 roku o Biurze Ochrony Rządu (t.j. Dz.U. z 2014 roku, poz. 170).

Ustawa z dnia 24 maja 2002 roku o Agencji Bezpieczeństwa Wewnętrznego oraz Agencji Wywiadu (t.j. Dz.U. z 2010 roku, nr 29, poz. 154 ze zm.). 
Ustawa z dnia 9 czerwca 2006 roku o Centralnym Biurze Antykorupcyjnym (t.j. Dz.U. z 2014 roku, poz. 1411).

Ustawa z dnia 9 czerwca 2006 roku o służbie funkcjonariuszy Służby Kontrwywiadu Wojskowego oraz Służby Wywiadu Wojskowego (t.j. Dz.U. z 2014 roku, poz. 1106).

Ustawa z dnia 27 sierpnia 2009 roku o Służbie Celnej (t.j. Dz.U. z 2013 roku, poz. 1404 ze zm.).

Wantoch-Rekowski J., System ubezpieczeń społecznych a budżet państwa. Studium prawno-finansowe, Warszawa 2014.

Wieczorek M., Prawne podstawy zatrudnienia w Agencji Bezpieczeństwa Wewnętrznego, [w:] Prawo bezpieczeństwa publicznego, pod red. M. Karpiuka, K. Walczuka, Warszawa 2013.

Wyrok Trybunału Konstytucyjnego z dnia 7 lutego 2006 roku, sygn. akt SK 45/04, OTK ZU nr 2/A/2006.

Wyrok Trybunału Konstytucyjnego z dnia 11 grudnia 2006 roku, sygn. akt SK 15/0, OTK ZU nr 11/A/2006, poz. 170.

Wyrok Trybunału Konstytucyjnego z dnia 29 kwietnia 2008 roku, P 38/06, OTK ZU nr 3/A/2008, poz. 46.

Wyrok Trybunału Konstytucyjnego z dnia 19 grudnia 2012 roku, K 9/12.

Wyrok Trybunału Konstytucyjnego z dnia 3 marca 2015 roku, K 39/13.

Wyrok Wojewódzkiego Sądu Administracyjnego w Warszawie z dnia 23 stycznia 2007 roku, II SA/Wa 2031/06, LEX nr 299847.

Wyrok Wojewódzkiego Sądu Administracyjnego w Warszawie z dnia 8 listopada 2010 roku, II SAB/Wa 180/10, LEX nr 756185.

Ziembiński Z., O pojmowaniu sprawiedliwości, Lublin 1991.

Ziembiński Z., Sprawiedliwość społeczna jako pojęcie prawne, Warszawa 1996.

\section{SUMMARY}

The study addresses the issue of social security of Customs Service officers. This occupational group, unlike other officers of so called uniformed services, has a social protection based on insurance technique, which means that in this area it has been made equal with the employees. However, the Customs Service officers are not empoyees within the meaning of the labour law and they are in a work relation regulated by the administrative law. The way of social security of Customs officers has raised objections of a constitutional nature, basing on the allegation of unequal treatment of the uniformed services, concerning excluding customs officers from the circle of uniformed services officers, benefiting from a more beneficial than an occupational social security system. This paper presents the thesis according to which the legislator has not violated the constitutional principle of equality before the law in relation to most customs officers, but only to those among them who carry out the duties generically close to the duties of police officers.

Keywords: service; equality; social security; Customs Service 